\section{DE DE GRUYTER OPEN

Research Article

(c) 2018 U. A. Asa and V. V. Nkan. This is an open access article licensed under the Creative Commons Attribution-NonCommercial-NoDerivs License (http://creativecommons.org/licenses/by-nc-nd/3.0/).

\title{
Social Capital and Contraceptive Use among Rural Dwellers in Akwa Ibom State, Nigeria
}

\author{
U. A. Asa \\ Department of Agricultural Economics and Extension, \\ University of Uyo, Uyo, Akwa Ibom State, Nigeria \\ V. V. Nkan \\ Department of Human Ecology, Nutrition and Dietetics, \\ University of Uyo, Uyo, Akwa Ibom State, Nigeria
}

Doi: 10.2478/mjss-2018-0100

\section{Abstract}

The study assessed the relationship between social capital and contraceptive use among rural dwellers in Akwa Ibom State, Nigeria. Data obtained from one hundred and sixty rural dwellers, using multi-stage sampling procedure, were analyzed using descriptive statistics. Results show that $51.3 \%$ of the respondents, with an average age of 40 years, were females and $71.3 \%$ were married. Majority of the respondents (96.2\%) had formal education with an average monthly income of N28,900.50. Results also reveal that a high level of social capital exists among $56.9 \%$ of the respondents; and that the most utilized contraceptive methods by the rural dwellers were barrier methods, hormonal contraceptives and abstinence. A simple linear regression shows that social capital positively influences contraceptive use by rural dwellers in the study area. Hence, social capital should be taken cognizance of by policy makers in the study area when formulating policies aimed at controlling the rural populace via contraceptive use.

Keywords: Social capital, contraceptive, rural dwellers, Akwa Ibom State

\section{Introduction}

Nigeria, with an estimated population of 140 million, is the most populous country in Africa, accounting for approximately one-sixth of the continent's population (www.urbanreproductiovehealth.org). High population growth rate in Nigeria, especially in the face of low productivity, have directly or indirectly been associated with different kinds of social problems ranging from poverty, scarcity of land, hunger and environmental degradation to political instability (Okoroafor, 2001). The rate of population growth in Nigeria is increasing at an alarming rate to the point that is even higher than the rate of food production in the country (Okezie et al, 2010). The population problem in Nigeria is more acute in the rural areas (Asa and Daniel, 2015).

Family planning, however, plays a pivotal role in population control, poverty reduction and human development (Longwe et al, 2012). It has been successfully used by countries such as Korea, Brazil, Columbia, China, India, Bangladesh and Malawi to arrest the dangers inherent in high population growth rate (Cohen, 2000). Nevertheless, contraceptive prevalence, according to Elfstrom and Stephenson (2012), is low in the African region despite considerable family planning programmatic efforts. In Nigeria, for example, contraceptive prevalence has increased by less than $0.5 \%$ per year since 1997 . This could be due to the fact that success of development programmes, especially in the rural areas of Nigeria, depends on - among others - the social capital of the clientele (Akpabio, 2008). Social capital, which can be viewed as the sum total of resources that accure to an individual by virtue of belonging to a network of more or less institutionalized 
relationship of mutual acquaintance and recognition (Sherif et. al, 2012), has increasingly gained recognition in many aspects of rural development in developing countries (Meinzen-Dick et. al., 2004). This is due to its perceived positive consequences for development and opportunities for those who lack possession of and access to financial, human or physical capital

Beuno et. al., (2007) posited that the availability of social networks in a society helps to control the fertility behaviour of individuals in the society. This is done by encouraging family planning and contraceptive use among members of a network. The intention to have a child, the value attributed to children, the norms regulating appropriate parenthood, the support available to parents and all other elements involved in childbearing decision-making are created, diffused and transformed by social interaction (Rossier and Bernardi, 2009). Attitudes as well as outcomes with respect to contraceptives and other health issues are affected by the strength of associations, community norms and knowledge through social networks (Kunitz, 2001). Social capital therefore plays a huge role in population control (Halpern, 2005). This study therefore assessed the relationship between the social capital of rural dwellers in Akwa Ibom State and their contraceptive use in order to provide relevant information that can enhance successful family planning programmatic efforts in the rural areas of the State. Akwa Ibom State was specifically selected for the study because of her alarming annual population growth rate of $3.4 \%$ which has led to increase in the population of the State from 3,920,208 to an estimated figure of 5,451,277 as at 2016 (www.akwaibomstate.gov.ng, 2016). Uncontrolled population growth is one of the principal causes of poverty in rural Africa; and poverty is more prevalent in the rural areas than the urban areas of Akwa lbom State (Umoh, 2002). The study specifically examined the socio-economic characteristics of rural dwellers in Akwa Ibom State; ascertained the social capital status of the respondents; determined the level of contraceptive use by the respondents; and ascertained the influence of social capital on contraceptive use by the respondents.

\section{Methodology}

The study was carried out in Akwa Ibom State of Nigeria. Akwa Ibom State is located in the SouthSouth geopolitical zone of Nigeria between latitudes $4^{0} 31^{\prime \prime}$ and $5^{0} 31^{\prime \prime}$ North, and longitudes $7^{0} 35^{\prime \prime}$ and $8^{\circ} 25^{\prime \prime}$ East. The State is bordered on the east by Cross River State, on the west by Rivers and Abia States and on the south by the Atlantic Ocean. The State occupies a total land area of $7,245,935 \mathrm{~km}^{2}$ and has an estimated population of 3,920,208 (National Population Commission, 2006). A multi-stage sampling procedure was used to select the sample for this study. The first stage involved the random selection of four out of the six Agricultural Development Project (ADP) zones in Akwa Ibom State - Abak, Ikot Ekpene, Oron and Uyo zones. The second stage involved the purposive selection of four villages in the rural areas of each of the selected ADP zones to make a total of sixteen villages. The purposive sampling procedure employed at the second stage ensured that only villages considered rural were selected for the study. A third stage of the multistage sampling procedure involved the random selection of ten persons from ten different households in each of the sixteen villages thereby resulting in a sample size of 160 . Frequency counts, percentages and means were used to analyze the socio-economic characteristics of rural dwellers in Akwa Ibom State. Social capital was measured in terms of six dimensions namely: group and networks; trust and solidarity, information and communication; collective action and cooperation; social cohesion and inclusion; and empowerment and political action. An individual's total social capital score was obtained by the summation of a respondent's responses to different questions raised on the aforementioned elements and to which different weights had been assigned (Akpabio, 2008) Respondents were thereafter categorized into low, average, and high levels of social capital. The level of use of contraceptives by the respondents was ascertained using a 10item scale. The items in the scale were identified through literature and focus group discussions (FGDs). Responses of the respondents were rated on a 3-point scale of Never Used, Rarely Used and Often Used (assigned with nominal values of 0,1 and 2 respectively). A mean score, computed for each of the items in the scale, was used to rank the level of use of each contraceptive method. A simple linear regression was used to test the influence of social capital on the extent of contraceptive use by the respondents. This was done using Statistical Package for Social Sciences 
(SPSS) Version 20.0. The simple linear regression model is stated as follows:

$y=f(x)$

where:

$y=$ Contraceptive use (duration of contraceptive use by the respondents)

$\mathrm{x}=$ Social capital (summated social capital scores of the respondents)

\section{Results and Discussion}

\subsection{Socio-economic characteristics of rural dwellers in Akwa Ibom State}

Table 1 shows the socio-economic characteristics of rural dwellers in Akwa Ibom State, Nigeria. Data from the Table reveals that $51.3 \%$ of the respondents were females and that the mean age of the respondents was 40 years. The finding corroborates Asa (2015) who reported that majority of rural dwellers in Akwa Ibom State were below 50 years. Majority of the respondents $(96.2 \%)$ were functionally literate indicating a high level of literacy among the respondents thereby agreeing with Asa (2006) who reported a high level of literacy among rural dwellers in Akwa Ibom State, Nigeria. Over seventy three percent $(73.1 \%)$ of the respondents were married while $26.9 \%$ were single. Asa and Solomon (2010) also reported in a previous study that majority of rural dwellers in Akwa Ibom State are married. Majority of the respondents (96.3\%) were Christians with an average monthly income of N28,500.50. The income level of the rural dwellers is relatively low thereby agreeing with Etim (2006) who reported that a low level of income exists among rural households in Akwa Ibom State. The Table also reveals that the average household size of the respondents comprised of seven person. The finding is very close Asa (2015) who reported that the average household size of rural dwellers in Akwa Ibom State comprised of six persons.

Table 1: Socio-economic characteristics of rural dwellers in Akwa Ibom State, Nigeria

\begin{tabular}{|c|c|c|c|c|}
\hline $\begin{array}{l}\text { Socio-economic } \\
\text { characteristics }\end{array}$ & Categories & $\begin{array}{l}\text { Frequency } \\
(\mathrm{n}=160)\end{array}$ & Percentage & Mean \\
\hline \multirow[t]{2}{*}{$\overline{S e x}$} & Male & 78 & 48.8 & \\
\hline & Female & 82 & 51.3 & \\
\hline \multirow[t]{5}{*}{ Age } & $21-30$ years & 24 & 15.0 & 40 \\
\hline & $31-40$ years & 61 & 38.1 & \\
\hline & $41-50$ years & 54 & 33.8 & \\
\hline & $51-60$ years & 19 & 11.9 & \\
\hline & $61-70$ years & 2 & 1.3 & \\
\hline \multirow[t]{5}{*}{ Educational status } & No formal education & 6 & 3.8 & \\
\hline & Primary education & 60 & 37.5 & \\
\hline & Secondary education & 53 & 33.1 & \\
\hline & Tertiary education & 23 & 14.1 & \\
\hline & Adult literacy education & n 18 & 11.3 & \\
\hline \multirow[t]{2}{*}{ Marital status } & Single & 43 & 26.9 & \\
\hline & Married & 117 & 73.1 & \\
\hline \multirow[t]{2}{*}{ Religion } & Christianity & 154 & 96.3 & \\
\hline & Non-Christianity & 6 & 3.8 & \\
\hline \multirow[t]{3}{*}{ Monthly income (in Naira) } & $1-40,000$ & 128 & 80.0 & $28,500.50$ \\
\hline & $40,001-80,000$ & 30 & 18.3 & \\
\hline & $80,001-120,000$ & 2 & 1.3 & \\
\hline \multirow[t]{3}{*}{ Household size } & $1-5$ person $(s)$ & 16 & 10.0 & 9 \\
\hline & $6-10$ persons & 93 & 58.1 & \\
\hline & $11-15$ persons & 51 & 31.9 & \\
\hline
\end{tabular}

Note: Naira (1) is the Nigerian currency and 1.00 US Dollar is equal to 199.02 Nigerian Naira as at September 18, 2015.

Source: Field survey, 2014 


\subsection{Social capital status of the respondents}

Table 2 shows the respondents' levels of social capital. The Table reveals that $59.9 \%$ of the rural dwellers had a high level of social capital, $30.0 \%$ had an average level of social capital while $13.1 \%$ had a low level of social capital. The findings agree with Akpabio (2008) who reported that a high level of social capital existed among members of farmers' organizations in Akwa lbom State. Morrow (2004) opined that communities have great social capital due to the prevalence of social and community networks, civic engagement, local identity, a sense of belonging, solidarity with other members of such community.

Table 2: Distribution of respondents based on levels of social capital

\begin{tabular}{llll}
\hline Levels of social capital & Social capital score & Frequency & Percentage \\
\hline Low & $31-47$ & 21 & 13.1 \\
Average & $48-64$ & 48 & 30.0 \\
High & $65-81$ & 91 & 56.9 \\
Total & & 160 & 100 \\
\hline
\end{tabular}

Source: Field survey, 2014

\subsection{Level of utilization of contraceptives by the respondents}

The level of usage of contraceptives by rural dwellers in Akwa Ibom State, Nigeria is shown in Table 3. The Table reveals that the most used contractive methods by the rural dwellers are barrier methods $(\bar{x}=0.90)$, hormonal contraceptives $(\bar{x}=0.67)$ and abstinence $(\bar{x}=0.66)$. The male condom -which is a barrier method - is probably the most widely used mechanical contraceptive in the world today (Burknam, 2007). The findings corroborate Olugbenga-Bello et al (2011) who also reported that barrier methods and hormonal contraceptives are the most utilized contraceptive methods in rural communities of South-Western Nigeria, and that these methods are popular among the rural dwellers because they serve the dual functions of preventing sexually transmitted infections and acting as family planning methods.

Table 3: Distribution of respondents based on level of utilization of contraceptive methods

\begin{tabular}{lll}
\hline Contraceptive methods & Mean & Rank* \\
\hline 1. Natural method & 0.59 & 4 \\
2. Contraceptive implant & 0.23 & 9 \\
3. Voluntary surgical contraception & 0.21 & 10 \\
4. Injectables & 0.49 & 5 \\
5. Abstinence & 0.66 & 3 \\
6. Intra-uterine devices (IUDs) & 0.41 & 6 \\
7. Barrier methods (condoms, diaphragm, etc) & 0.90 & 1 \\
8. Coitus interruptus & 0.32 & 7 \\
9. Hormonal contraceptives (pills) & 0.67 & 2 \\
10. Sterilization & 0.26 & 8 \\
\hline
\end{tabular}

Note:* = rank 1 is considered the most utilized contraceptive method while rank 10 is the least utilized method

Source: Field survey, 2014 
On the other hand, Table 3 indicates that sterilization $(\bar{x}=0.26)$, contraceptive implant $(\bar{x}=0.23)$ and voluntary surgical contraception $(\bar{x}=0.21)$ were the least used contraceptive methods by the rural dwellers. This could be due to the high cost associated with sterilization which hinder the rural dwellers from using sterilization as a contraceptive method as well as the negative perception of effects of contraceptive implant and voluntary surgical contraceptive methods by the rural dwellers.

\subsection{Relationship between the respondents' social capital and their contraceptive use}

Table 4 shows the result of the regression analysis of influence of the respondents' social capital on their contraceptive use. The regression coefficient of the independent variable (social capital) is 0.073 and is significant at $5 \%$ level indicating that an increase in the level of the respondents' social capital will lead to 0.073 increase in their level of contraceptive use. The finding suggests that contraceptive use decision by the respondents is influenced by their social capital. The result corroborates Yee and Simon (2010) who reported that contraceptive use is positively impacted by social capital.

Table 4: Influence of social capital on contraceptive use by the respondents

\begin{tabular}{llll}
\hline Variable & Coefficient & Standard error & $\mathrm{t}$ \\
\hline Social capital & 0.073 & 0.032 & $2.276^{* *}$ \\
Constant & 0.899 & 0.165 & 5.452 \\
$\mathrm{R}^{2}$ & 0.568 & & \\
\hline
\end{tabular}

Note: ${ }^{* *}=$ contraceptive use; dependent variable: contraceptive use

Source: SPSS Version 20.0 Computer Printout, 2014

\section{Conclusion and Recommendations}

The study ascertained the relationship between the social capital of rural dwellers in Akwa Ibom State, Nigeria and their contraceptive use. The study revealed that a high level of social capital exists among majority of the respondents; and that the most used contraceptive methods by the respondents are barrier methods, hormonal contraceptives and abstinence. The study also revealed that the respondents' contraceptive use is positively impacted by their social capital. This makes social capital an issue of interest to policy makers in the study area who wish to control the rural population via contraceptive use. Again, the Government of Akwa Ibom State in collaboration with Non-Governmental Organizations (NGOs) in the study area should endeavour to organize enlightenment programmes on contraceptive use specifically targeted at rural areas in the State. These enlightenment programmes should aim at overcoming the negative perceptions of use of certain contraceptive methods by rural dwellers in the State.

\section{References}

Akpabio, I. A. (2008) Significant predictors of social capital in farmers organizations in Akwa Ibom State, Nigeria, The Journal of International Social Research, 1(3): 45-59

Asa, U. A. (2006) Perceived effect of Akwa Rubber Estates Limited (AKRUBEL) on rural livehoods in Akwa Ibom State, Nigerian Journal of Agriculture, Food and Environment, 3(1 \& 2): 52-55

Asa, U. A. (2015) Constraints to mobile phones utilization by rural dwellers in Akwa lbom State, Nigeria, International Journal of Information and Communication Technology Research, 5(2): 28-34

Asa, U. A. and Daniel, E. A. (2015) Barriers to contraceptive use among rural famers in Akwa lbom State, Nigeria, International Journal of Agricultural Extension and Rural Development Studies, 2(1): 22-29

Asa, U. A. and Solomon, V. A. (2010) Gender participation in livehood activities of rural dwellers in Akwa Ibom State, Nigeria, International Journal of Applied Agricultural and Apicultural Research, 6(1 \& 2): 57-64 
Beuno, E., Salmador, M.P and Rodriguez, O. (2007) The role of social capital in today's economy: Empirical evidence and proposal of a new model of intellectual capital, Journal of Intellectual Capital, 5(4): 556-574.

Burknam (2007) Contraception and family planning (In) Decherney, A. H., Godwin, T.M., Lauren, N. and Laufer, N. (eds) Current Obstetrics and Gynaecology: Diagnosis and Treatment, McGraw-Hill USA, pp 579-597

Cohen, B. (2000) Family planning programs, socio-economic characteristics and contraceptive use in Malawi, World Dec., 28(5): 843-860

Elfstrom, K. M. and Stephenson, R. (2012) The role of place in shaping contraceptive use among women in Africa. PLoS ONE 7(7): e40670.doi:10.1371/journal.pone.0040670

Etim, N. A. (2006) Analysis of poverty status of rural farm households in Akwa lbom State, Nigeria, Ph.D, Michael Okpara University of Agriculture, Umudike. 135pp

Halpern, D. (2005) Social Capital. Cambridge: Polity Press

Kunitz, S.J. (2001) Accounts of social capital (In) Leon, D. A. and E. Walt (eds) Poverty, Inequality and Health: An International Perspective, Oxford: Oxford University Press

Longwe, A., J. Huisman and J. Smits (2012) Effects of knowledge, acceptance and use of contraceptives on household wealth in 26 African countries, NiCE Working Paper 12-109, Institute for Management Research, Radbond University Nijmegen, The Netherlands. 29pp

Meinzen-Dick, R., D. Gregorio and McCarthy, N. (2004) Methods for studying collective action in rural development, Agricultural systems, 82(3): 197-214.

Morrow, V. (2004) Young people's explanation and experiences of social exclusion: Retrieving Bourdien's concept of social capital. International Journal of Sociology and Social Policy, 21(415/6): 37-63

National Population Commission (2006) Population and Housing census of the Federal Republic of Nigeria. Analytical Report at the National Population Commission, Abuja, Nigeria

Okezie, C.A., A. O. Ogbe and C. R Okezie (2010) Socio-economic determinants of contraceptive use among rural women in Ikwuano Local Government Area of Abia State, Nigeria, International NGO Journal, 5(4): 74-77

Okorafor, O. E. (2001) Large Families: Causes, consequences and cures. Spring Field Publishers Ltd., Owerri

Olugbenga-Bello, A. I., Abodunrin, O.L. and Adeomi, A. A. (2011) Contraceptive practices among women in rural communities in South Western Nigeria, Global Journal of Medical Research, 11(1): 14-16

Rossier, C. and Bernardi, L. (2009) Social interaction effects on fertility: Intentions and Behaviors, European Journal of Population, 25(4): 467-485

Sherif, K., Munasinghe, M. and Sharma, C. (2012) The combinative effect of electronic open network and closed interpersonal networks on knowledge creation in academic communities, Journal of Information and Knowledge Management Systems, 42(2): 277-294

Umoh, G. S. (2002) Resource use and human security in the Niger Delta: The challenge to sustainable development in Nigeria, Nigerian Journal of Rural Sociology, 5(2): 29-35

www.akwaibomstate.gov.ng (2016) Akwa Ibom State History - Akwa Ibom State Government. Accessed on October 23, 2016

www.urbanrepoductivehealth.org (2015) Measurement, Learning and Evaluation Project for the Urban Reproductive Health Initiative. Accessed on March 31, 2015

Yee, L. and M. Simon (2010) The role of the social network in contraceptive decision-making among young African American and Latin women, Journal of Adolescent Health, 47(10): 374-380 